\title{
Pengisian Jabatan Hakim: Kebutuhan Reformasi dan Pengekangan Diri
}

\author{
Susi Dwi Harijanti \\ Fakultas Hukum Universitas Padjadjaran Bandung \\ Jl. Dipati Ukur No. 35 Bandung 40132 \\ s.harijanti@unpad.ac.id
}

\begin{abstract}
For more than 30 years, a discourse regarding the selection of judges has become a hot issue around the world for several reasons. It is mainly related to the primary function of the courts to resolve disputes that may affect the lives of individuals and society. Problems posed, first, how filling the positions of justices and judges in the Indonesian constitution of post-reform? Second, how is the ideal concept in filling the positions of justices and judges of the constitution? This research is doctrinal, using primary and secondary legal materials, in the form of some legislation, literature and research results which are relevant to the object of research. The approach used in this study is the approach of legislation and conceptual approaches. The study concluded, first, filling the positions of Chief Justice and Judges of the Constitutional shows that it is more politicking because of the participation of the People's Representative Council or Parliament. Secondly, the renewal and principle of self-restraint need to be done by each branch of power to minimize political bias.
\end{abstract}

Keywords: Selection of judges, renewal, and principle of self-restraint.

\begin{abstract}
Abstrak
Selama lebih dari 30 tahun diskursus mengenai seleksi hakim menjadi isu hangat di seluruh dunia karena beberapa alasan, terutama berkaitan dengan fungsi utama pengadilan yakni penyelesaian sengketa yang dapat mempengaruhi kehidupan perseorangan maupun masyarakat. Permasalahan yang diajukan, pertama, bagaimana pengisian jabatan hakim agung dan hakim konstitusi di Indonesia pasca reformasi? Kedua, bagaimana konsep yang ideal dalam pengisian jabatan hakim agung dan hakim konstitusi? Penelitian ini merupakan penelitian doktrinal, dengan menggunakan bahan hukum primer dan sekunder, berupa beberapa peraturan perundang-undangan, literatur dan hasil-hasil penelitian yang relevan dengan objek penelitian. Pendekatan yang digunakan dalam penelitian ini adalah pendekatan perundang-undangan dan pendekatan konseptual. Penelitian ini menyimpulkan, pertama, pengisian jabatan Hakim Agung dan Hakim Konstitusi menunjukkan lebih bersifat politicking karena keikutsertaan Badan Perwakilan Rakyat atau Parlemen. Kedua, pembaharuan dan prinsip pengekangan diri perlu dilakukan oleh masing-masing cabang kekuasaan untuk meminimalkan bias politik.
\end{abstract}

Kata kunci: Seleksi hakim, pembaharuan, dan prinsip pengekangan diri. 


\section{Pendahuluan}

Hakim dalam penelitian ini merujuk pada Hakim Agung dan Hakim Konstitusi. Penelitian ini sengaja membatasi pada kedua jenis jabatan tersebut dengan beberapa alasan. Pertama, Mahkamah Agung dan Mahkamah Konstitusi menduduki hirarki tertinggi dalam struktur di Indonesia. Kedua, karena menduduki kedudukan tertinggi tersebut, maka Hakim Agung dan Hakim Konstitusi memeriksa dan memutus perkara-perkara penting yang dapat mempengaruhi kehidupan individu dan masyarakat (misalnya hak dan kewajiban) serta penyelenggaraan negara dan pemerintahan.

Kekuasaan kehakiman atau kekuasaan peradilan merupakan suatu jabatan yang selalu ada dalam setiap sistem ketatanegaraan. Bahkan, kekuasaan kehakiman adalah salah satu alat kelengkapan negara yang memiliki fungsifungsi fundamental. Fungsi utama dan pertama adalah memutus sengketa (resolving disputes) antara individu dengan individu, individu dengan masyarakat, bahkan individu atau masyarakat dengan negara. Fungsi kedua adalah membentuk atau membuat policy atau kebijakan. ${ }^{1}$ Meskipun putusan pada dasarnya berlaku untuk para pihak, terutama untuk perkara-perkara perdata, namun acapkali terjadi putusan-putusan tersebut mempengaruhi kebijakankebijakan umum. Bahkan tidak jarang juga mempengaruhi perkembangan ekonomi. Di Amerika Serikat, fungsi ini sangat terlihat dalam seratus tahun terakhir sebagai akibat perkembangan progresivisme di kalangan Hakim Agung yang secara signifikan menyumbangkan perubahan-perubahan ketatanegaraan. ${ }^{2}$ Fungsi lainnya adalah mengawasi tindakan-tindakan pemerintah. Konkretisasi fungsi jabatan kekuasaan kehakiman dilaksanakan oleh para hakim yang dilengkapi oleh berbagai hak dan kewajiban.

Saat suatu negara merancang sistem peradilannya, terdapat beragam persoalan yang dihadapi yang tidak hanya terbatas pada struktur dan kompetensi pengadilan. Salah satu persoalan pelik berkenaan dengan syarat-syarat,

1 Walter F. Murphy, et., al, Courts, Judges \& Politics, An Introduction to the Judicial Process, Sixth Edition, McGraw Hill, Boston, 2005, hlm. 45.

${ }^{2}$ Bradley C.S Watson, Living Constitution, Dying Faith: Progressivism and the New Science of Jurisprudence, ISI Books, Wilmington, Delaware, 2009, hlm. xvii 
mekanisme pengisian jabatan kekuasaan kehakiman, terutama hakim, serta lamanya seseorang menjadi hakim. Salah satu alasan mengapa seleksi hakim menjadi persoalan mendasar karena seleksi akan mempengaruhi, bahkan menghasilkan tipe-tipe orang yang bertugas sebagai hakim, termasuk pilihanpilihan yang dibuat oleh mereka sebagai hakim. ${ }^{3}$ Keseluruhan ketentuan mengenai syarat, mekanisme pengisian jabatan serta masa jabatan hakim dimaksudkan demi terwujudnya kekuasaan kehakiman yang merdeka serta kebebasan hakim.

\section{Rumusan Masalah}

Permasalahan yang diajukan dalam penelitian ini, pertama, bagaimanakah pengisian jabatan hakim agung dan hakim konstitusi di Indonesia pasca reformasi? Kedua, bagaimana konsep yang ideal dalam pengisian jabatan hakim agung dan hakim konstitusi?

\section{Tujuan Penelitian}

Penelitian ini bertujuan untuk mengetahui, pertama, pengisian jabatan hakim agung dan hakim konstitusi di Indonesia pasca reformasi. Kedua, konsep yang ideal dalam pengisian jabatan hakim agung dan hakim konstitusi.

\section{Metode Penelitian}

Penelitian ini merupakan penelitian doktrinal, dengan menggunakan bahan hukum primer dan sekunder, berupa beberapa peraturan perundangundangan, literatur dan hasil-hasil penelitian yang relevan dengan objek penelitian. Pendekatan yang digunakan dalam penelitian ini adalah pendekatan perundang-undangan, pendekatan komparatif, dan pendekatan konseptual. Sedangkan bahan-bahan yang terkumpul akan dianalisis secara deskriptif kualitatif.

${ }^{3}$ Walter F. Murphy, Op. Cit., hlm. 141. 


\section{Hasil Penelitian dan Pembahasan}

\section{Jabatan, pejabat dan pengisian jabatan}

Negara merupakan sebuah organisasi yang memiliki beberapa unsur inti, yaitu: (1) Alat-alat kelengkapan organisasi yang lazim dikenal sebagai alat-alat kelengkapan negara atau organ negara. Organ negara ini disebut pula sebagai jabatan yang memiliki berbagai fungsi. Secara umum, jabatan diartikan sebagai 'lingkungan kerja tetap yang berisi fungsi-fungsi tertentu yang secara keseluruhan mencerminkan tujuan dan tata kerja suatu organisasi', yang dalam hal ini tujuan dan tata kerja negara.4 (2) Dalam praktik, lingkungan jabatan dalam organisasi negara dibagi menjadi beberapa jenis: ${ }^{5}$ a. Jabatan alat kelengkapan negara (organ negara) - jabatan penyelenggara administrasi negara. b. Jabatan politik - jabatan non politik. c. Jabatan yang secara langsung bertanggung jawab dan berada dalam kendali atau pengawasan publik - jabatan yang secara tidak langsung bertanggung jawab dan berada dalam kendali atau pengawasan publik. d. Jabatan yang secara langsung melakukan pelayanan publik - jabatan yang secara tidak langsung melakukan pelayanan publik. (3) Pejabat-pejabat yang menduduki jabatan-jabatan. Tanpa pejabat, jabatan-jabatan yang bersifat abstrak tidak dapat menjalankan fungsinya. (4) Tugas dan wewenang yang melekat pada pejabat guna melaksanakan fungsi jabatan.

Sebagaimana telah disebutkan, jabatan-jabatan tanpa pejabat akan senantiasa bersifat abstrak, dan oleh karenanya membutuhkan kehadiran pejabat untuk mengkonkritkan jabatan-jabatan tersebut. Mengikuti konstruksi berpikir seperti ini maka pengisian jabatan menjadi suatu keharusan. Secara umum pengisian jabatan dapat dilakukan dengan dua cara, yaitu cara autokrasi atau otoriter dan cara demokrasi. ${ }^{6}$ Dikatakan autokrasi atau otoriter apabila pengisian dilakukan oleh sekelompok kecil pemegang kekuasaan dan calon berasal dari lingkungannya sendiri.7 Dengan demikian, dapat dipastikan cara pengisian yang otoriter ini menjauhkan dan meniadakan keikutsertaan rakyat. Sebaliknya, cara

\footnotetext{
${ }^{4}$ Bagir Manan, Teori dan Politik Konstitusi, FH UII Press, Yogyakarta, 2003, hlm. 64.

${ }^{5}$ Ibid.

${ }^{6}$ Usep Ranawijaya, Hukum Tata Negara Indonesia: Dasar-dasarnya, Ghalia Indonesia, Jakarta, 1983, hlm. 211. ${ }^{7}$ Ibid.
} 
pengisian yang demokratis mendekatkan dan memaksimalkan partisipasi rakyat, karena didasarkan pada asumsi bahwa tidak ada urusan negara yang luput dari jangkauan dan kendali rakyat. ${ }^{8}$ Kedua cara pengisian ini sangat bertolak belakang dan secara eksplisit Usep Ranawijaya menyatakan, 'kedua paham ini tidak mungkin dipertemukan atau dikompromikan satu sama lain'. ${ }^{9}$

Penetapan autokrasi mengambil bentuk-bentuk berupa: ${ }^{10}$ a. Penetapan berdasarkan keturunan; b. Koopsi, yaitu penundukan bakal penguasa oleh pejabat kekuasaan yang ada; c. Pengundian; d. Pengangkatan pejabat oleh pejabat yang lebih tinggi kedudukannya; e. Penetapan pejabat dengan perebutan kekuasaan. ${ }^{11}$ Sedangkan pengisian yang demokratis diwujudkan dalam beberapa cara, terutama melalui pemilihan (election). Lembaga yang tumbuh untuk keperluan tersebut meliputi, antara lain, lembaga perwakilan, lembaga pemilihan umum, dan lembaga kepartaian. Pengisian dengan cara ini juga menuntut persyaratan-persyaratan tertentu, misalnya pemilihan umum harus diselenggarakan secara terbuka, jujur, adil, dan langsung. Selain itu, diperlukan jaminan hak untuk menyatakan pendapat, berkumpul, berapat, termasuk kebebasan pers. Meskipun secara teori, sistem pengisian sebagaimana dikemukakan oleh Usep Ranawijaya dapat dibenarkan, namun tampaknya tidak dapat diberlakukan untuk seluruh pengisian jabatan karena cara pengisian tersebut cenderung lebih tepat untuk jabatan-jabatan politik.

Agak berbeda dengan Usep Ranawijaya, Bagir Manan menjelaskan terdapat dua hal penting berkenaan dengan sistem pengisian jabatan. ${ }^{12}$ Pertama, apakah pengisian memerlukan atau tidak memerlukan partisipasi atau dukungan rakyat (publik). Kedua, apakah pengisian jabatan harus dilakukan secara kolegial atau oleh perorangan tertentu. Lebih lanjut dinyatakan oleh Bagir Manan, bahwa perbedaan sistem tersebut penting bukan hanya berkaitan dengan tata cara atau

${ }^{8}$ Ibid.

${ }^{9}$ Ibid.

${ }^{10}$ Ibid., hlm. 211-212.

11 Perebutan kekuasaan sendiri dilakukan melalui berbagai cara, seperti coup d'etat, revolusi, dan lain-lain. Coup d'etat adalah perebutan kekuasaan yang dipimpin dari luar dan dilakukan di luar pemerintahan dengan tujuan membebaskan alat-alat birokrasi dan alat-alat kekuasaan negara dari kepemimpinan politik yang ada. Sedangkan revolusi adalah satu penumbangan kekuasaan oleh kekuatan massa rakyat tanpa suatu koordinasi dengan tujuan mengubah tertib politik, sosial dan kepemimpinan negara. Ibid., hlm. 212.

${ }^{12}$ Bagir Manan, Teori..., Op. Cit., hlm. 66. 
prosedur, namun berkenaan pula dengan pertanggungjawaban dan pengawasan serta kendali terhadap pemangku jabatan, termasuk kebutuhan akan pembatasan masa jabatan. ${ }^{13}$ Misalnya, jabatan-jabatan politik karena membutuhkan pertanggungjawaban secara langsung kepada rakyat, maka pada umumnya dilakukan pembatasan masa jabatan. Sebaliknya, jabatan administrasi negara dan jabatan-jabatan profesional lainnya tidak memerlukan pembatasan karena tidak secara langsung bertanggung jawab kepada rakyat. Kalaupun terdapat pembatasan, biasanya didasarkan pada kriteria umur.

Dalam konteks pengisian jabatan kekuasaan kehakiman, secara teori sangat dipengaruhi oleh sistem hukum yang dianut oleh negara yang bersangkutan. Meskipun demikian, praktik menunjukkan adanya perkembangan pengisian jabatan yang tidak lagi seutuhnya tunduk pada sistem hukum tersebut.

\section{Hakim dan Sistem Hukum}

Meskipun dikenal beberapa sistem hukum, ${ }^{14}$ namun secara umum dikenal dua sistem hukum yang dominan di dunia ini, yaitu sistem hukum Eropa Kontinental dan sistem hukum Anglo Saxon. Kedua sistem ini meletakkan fungsi hakim secara berbeda, yang pada gilirannya mempengaruhi proses seleksi. John Henry Merryman mengatakan bahwa dalam sistem hukum Anglo Saxon, hakim dipandang sebagai 'a culture hero', bahkan acapkali dikatakan sebagai figur seorang ayah..$^{15}$ Tradisi hukum di Anglo Saxon dibangun dan dikembangkan dari tangan hakim. Oleh karena itu, di negara-negara yang menganut tradisi ini, hakim menjadi figur yang lebih dikenal dibandingkan dengan pembuat undangundang. Sejumlah nama hakim yang sangat terkenal misalnya, Sir Edward Coke, John Marshall, Oliver Wendell Holmes, dan Benjamin N. Cardozo.

Peran sentral hakim dalam penyelenggaraan negara dalam membangun dan mengembangkan hukum diwujudkan dalam berbagai bentuk penafsiran yang sangat ekstensif, meskipun berbagai peraturan perundang-undangan yang

${ }^{13}$ Ibid.

${ }^{14}$ Lihat, misalnya René David dan John E.C. Brierly, Major Legal Systems in the World Today, New York, The Free Press, 1978. Mary Ann Glendon, et., al, Comparative Legal Traditions, Second Edition, West Publishing Co, St. Paul, Minn, 1994.

15 John Henry Merryman, The Civil Law Tradition, Second Edition, Standford University Press Standford, California, 1985, hlm. 34. 
ada, sah menurut hukum. Meskipun di Amerika Serikat atau di negara-negara penganut sistem Anglo Saxon ungkapan 'judicial supremacy' kurang disukai, namun praktik yang ada secara nyata menggambarkan supremasi kekuasaan kehakiman tersebut. ${ }^{16}$

Mengingat peran penting hakim dalam sistem Anglo Saxon, maka pengisian jabatan hakim menjadi sangat terpengaruh oleh peran tersebut. Hakim di sistem ini bukanlah jabatan yang dibangun berdasarkan karir, melainkan diisi oleh orang-orang yang sudah berpengalaman menjadi pengacara di berbagai institusi, baik swasta maupun pemerintah. Mereka dipilih ataupun diangkat menjadi hakim karena berbagai alasan, seperti sukses dalam karirnya sebagai pengacara, reputasi diantara para kolega pengacara, ataupun karena pengaruh politik. ${ }^{17}$ Pengisian dilakukan melalui beragam mekanisme. Di Amerika Serikat, misalnya, melibatkan Senat melalui the Judiciary Committee, yang biasanya dilengkapi oleh surat yang berfungsi sebagai endorsement dari Jaksa Agung dan nominasi dari Presiden. ${ }^{18}$ Karena sudah berkarir sebelumnya, maka umumnya mereka menjadi hakim pada saat usia yang tidak lagi muda. Oleh karenanya saat mereka dipilih atau diangkat menjadi hakim, pengangkatan tersebut dipandang sebagai sebuah pengakuan yang pada gilirannya akan menimbulkan rasa hormat dan prestige. ${ }^{19}$

Sebaliknya, hakim-hakim di sistem Eropa Kontinental mempunyai peran yang sangat berbeda dengan para kolega mereka di Anglo Saxon. Salah satu perbedaan mendasar, umumnya para hakim di negara-negara Eropa Kontinental adalah jabatan karir yang dibangun dari level paling bawah, yaitu pada pengadilan-pengadilan tingkat pertama. Oleh karena itu, tidak mengherankan image hakim di negara-negara Eropa Kontinental adalah sebagai pegawai negeri yang melaksanakan fungsi penting tetapi tidak menunjukkan kreativitas yang berarti. Dalam kalimat Merryman, 'a civil servant who performs important but essentially uncreative functions'. ${ }^{20}$ Hal ini, antara lain, dikarenakan pelatihanpelatihan bagi para hakim lebih menekankan pada kemampuan teknik-teknik

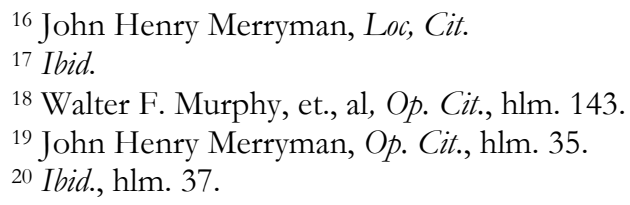


interpretasi atau penafsiran, daripada isu-isu besar yang seringkali terdapat dalam perkara-perkara pengujian konstitusional. ${ }^{21}$ Padahal, sebagaimana diargumentasikan oleh Mauro Cappelletti, ajudikasi atau pemeriksaan perkaraperkara ketatanegaraan atau konstitusional seringkali membutuhkan 'higher sense of discretion than the task of interpreting ordinary statues'. Namun, pelatihanpelatihan yang diikuti oleh para hakim Eropa Kontinental tidak dapat menopang kemampuan melakukan penafsiran konstitusi (constitutional interpretation). ${ }^{22}$

Lulusan pendidikan tinggi hukum dapat memilih hakim sebagai salah satu pilihan karir melalui ujian. Jika berhasil, mereka akan diangkat sebagai hakim yunior. Di Perancis, Spanyol, dan Jepang, terdapat sekolah khusus untuk pelatihan hakim. ${ }^{23}$ Kalau berhasil, para hakim yunior akan naik ke jenjang yang lebih tinggi atas dasar kombinasi dua hal: kemampuan dan senioritas. ${ }^{24}$ Selain itu, umumnya para hakim tergabung dalam organisasi hakim yang memiliki concern pada isu-isu perbaikan kondisi kerja, gaji, serta masa jabatan hakim. ${ }^{25}$

Perbedaan peran tersebut muncul karena keberadaan tradisi kekuasaan kehakiman yang berbeda di sistem Eropa Kontinental, yang dimulai pada masa Romawi. ${ }^{26}$ Sebelum masa Kekaisaran Romawi, hakim (iudex) adalah orang biasa yang memiliki fungsi memutus berdasarkan ketentuan yang dibuat oleh praetor (pembentuk undang-undang). Hakim di Romawi Kuno bukanlah seorang ahli hukum yang terkenal dan memiliki kewenangan yang terbatas. ${ }^{27}$ Jika membutuhkan nasihat hukum, iudex akan bertanya pada jurisconsult atau ilmuwan hukum (legal scholar). ${ }^{28}$ Selama masa Kekaisaran, penyelesaian sengketa lebih banyak dilakukan oleh pejabat publik, sedangkan hakim semata-mata berfungsi melaksanakan perintah atau keinginan Kaisar. Atau dengan kata lain, hakim tidak memiliki kewenangan melekat sebagai pembentuk hukum. ${ }^{29}$ hlm. 457 .

${ }^{21}$ Vicky C. Jackson dan Mark Tushnet, Comparative Constitutional Law, Foundation Press, New York, 1999,

22 Ibid.

${ }^{23}$ Mary Ann Glendon, et., al, Comparative..., Op.Cit., hlm. 156.

${ }^{24}$ John Henry Merryman, Op. Cit., hlm. 35.

25 Ibid.

${ }^{26}$ Ibid.

${ }^{27}$ Ibid.

${ }^{28} \mathrm{Ibid}$.

${ }^{29}$ Ibid. 
Terbatasnya peran hakim di negara-negara penganut sistem Eropa Kontinental, terutama di Perancis, antara lain dipengaruhi oleh Revolusi Perancis dan doktrin pemisahan kekuasaan. Kekuasaan kehakiman menjadi salah satu target Revolusi Perancis karena hakim-hakim tersebut selain sangat berpihak pada penguasa aristokrat, juga dikarenakan kegagalan mereka untuk membedakan secara jelas antara menerapkan hukum dan membentuk atau membuat hukum. ${ }^{30}$ Hakim seringkali tidak bersedia menerapkan undang-undang yang baru dibentuk oleh badan legislatif atau memberikan penafsiran yang berbeda dengan original intent pembentuk undang-undang. Oleh karena itu, Montesquieu mengembangkan doktrin pemisahan kekuasaan agar kekuasaan legislatif dan eksekutif terpisah dari kekuasaan yudikatif, serta memastikan kekuasaan yudikatif menerapkan undang-undang yang ditetapkan oleh badan legislatif serta tidak mempengaruhi kekuasaan eksekutif untuk melaksanakan fungsi-fungsi administrasi. ${ }^{31}$

Kondisi di atas tidak dijumpai di Amerika Serikat maupun di Inggris, karena dua negara tersebut mempunyai tradisi peradilan dimana hakim berperan penting melindungi hak-hak individu dari kekuasaan sewenang-wenang penguasa, serta menjadi bagian penting dari gerakan meruntuhkan feodalisme. Atas dasar ini maka tidak didapati kekhawatiran munculnya pembentukan hukum oleh hakim (judicial lawmaking) dan campur tangan pengadilan (judicial interference) terhadap pelaksanaan fungsi administrasi. ${ }^{32}$

Namun, seiring dengan munculnya pembentukan Mahkamah Konstitusi di beberapa negara Eropa Kontinental, misalnya Austria, Italia, Jerman dan Spanyol, yang melaksanakan fungsi penilaian konstitusionalitas undang-undang terhadap undang-undang dasar, pandangan tradisional mengenai hakim-hakim Eropa Kontinental mulai berubah. Bahkan, pendirian peradilan tersendiri yang terlepas dari sistem peradilan umum tersebut, dimaksudkan pula sebagai jawaban atas 'lemahnya legitimasi peradilan umum'.33 Hal ini disebabkan para Hakim Konstitusi harus memiliki kualifikasi, kemampuan (skills) serta kecerdasan untuk

\footnotetext{
${ }^{30}$ Ibid., hlm. 16.

${ }^{31}$ Ibid.

32 Ibid.

33 Vicky C. Jackson dan Mark Tushnet, Op. Cit., hlm. 458.
} 
meningkatkan legistimasi peradilan saat terlibat dalam 'kegiatan-kegiatan politik' ketika melakukan review terhadap undang-undang. ${ }^{44}$ Berbagai pandangan serta perkembangan mengenai fungsi hakim di atas mengakibatkan terdapatnya beragam syarat serta prosedur dan mekanisme pengisiannya.

\section{Syarat-syarat dan Model-model Seleksi Hakim}

Berkenaan dengan pengisian jabatan kekuasaan kehakiman ini, M.P. Jain dalam bukunya "Constitutional Law of India", menulis:

"The main purpose underlining the law laid down by the SC in the matter of opportunity Supreme Court judges was to minimize political influence in judicial appointments as well as to minimize individual discretion of the constitutional functionaries invoked in the process of appointment of the Supreme Court. The entire process of making appointment to high judicial offices is sought to be made more transparent so as to ensure that neither political bias, nor personal favoritism nor animosity play any part in the appointment of judges" ${ }^{35}$

Kutipan di atas menegaskan beberapa prinsip yang harus diperhatikan berkaitan dengan pengisian jabatan Hakim Agung (dalam artikel ini termasuk Hakim Konstitusi). Adalah penting meminimalkan pengaruh politik dalam proses pengangkatan serta menghindari sejauh mungkin diskresi individual pejabat yang berwenang dalam proses tersebut. Selain itu, keseluruhan proses diupayakan agar lebih terbuka untuk menjamin tidak terjadi bias politik ataupun preferensi atas calon tertentu. Atau dengan kata lain, merit selection system harus lebih diutamakan.

Dalam pada itu, terlepas dari berbagai konteks, seluruh bentuk rekruitmen hakim memiliki elemen-elemen tertentu yang sama yang dijumpai hampir di seluruh negara. Berbeda dengan rekruitmen untuk jabatan-jabatan negara atau pemerintahan lainnya yang secara nyata memperlihatkan karakter politik, prinsip fundamental kekuasaan kehakiman yang independen (judicial independence) memainkan peran yang sangat penting dalam proses pengisian jabatan tersebut. Selain itu, pada umumnya, para calon menyadari adanya standar yang tinggi,

\footnotetext{
${ }^{34}$ Ibid.

35 M.P Jain, Indian Constitutional Law, $5^{\text {th }}$ edition, Wadhwa Publisher Nagpur, 2006, hlm. 195-196.
} 
baik standar kualifikasi maupun standar moral, yang akan diberlakukan untuk mereka.

Berkenaan dengan berbagai jenis model rekruitmen, terdapat dua model ideal dalam rentang spektrum, yaitu: model independen profesional (the professionalindependent model) dan model politik-akuntabilitas-responsif (the responsiveaccountable-political model). ${ }^{36}$ Menurut model pertama, hakim harus mampu menegakkan konstitusi dan undang-undang yang sejalan dengan prinsip kepentingan umum. Model ini umumnya lebih mudah dilaksanakan di sistem Eropa Kontinental dimana hakim merupakan profesi yang lebih dekat pada jabatan birokrat sehingga saat hakim memutuskan suatu perkara campur tangan politik hampir tidak ada. Selain itu, tidak terdapat isu mengenai ideologi politik hakim. ${ }^{37}$ Sebaliknya, model kedua memiliki pandangan berbeda mengenai peran peradilan dalam sistem politik. Ada kekhawatiran apabila terdapat pengekangan politik, maka hakim dapat saja memiliki agenda-agenda tertentu sesuai dengan kepentingannya yang mengakibatkan kepentingan umum tidak terpenuhi. Oleh karena itu, pemilihan hakim dipandang sebagai suatu cara menjamin akuntabilitas yang pada gilirannya memungkinkan masyarakat serta para wakilnya menjamin terwujudnya peradilan yang responsif terhadap kebutuhan masyarakat, antara lain melalui mekanisme impeachment. ${ }^{38}$ Atas dasar tersebut David A. Yalof, menyatakan:

The interest in independence and accountability are irreducibly contradictory and context-dependent preferences. Still, judicial recruitment may be best understood according to how specific mechanisms strike a balance between these principles. ${ }^{39}$

Dalam kerangka model-model di atas, paparan di bawah akan menunjukkan bagaimana model tersebut terefleksi dalam rekruitmen hakim melalui berbagai persyaratan serta prosedur dan mekanisme.

\section{Syarat-syarat}

Negara manapun di dunia ini menghendaki memiliki hakim yang bermoral dan berintegritas tinggi, memiliki pengetahuan yang memadai, jujur,

${ }^{36}$ David A. Yalof, 'Filling the Bench' dalam Keith E. Whittington, et., al (eds), The Oxford Handbook of Law and Politics, Oxford University Press, Oxford, 2008, hlm. 471.

${ }^{37}$ Ibid.

${ }^{38}$ Ibid.

${ }^{39}$ Ibid. 
imparsial, dan independen saat memeriksa dan memutus perkara. Untuk itu, dibentuk aturan-aturan yang mengatur persyaratan menjadi hakim. Dalam konteks Hakim Konstitusi, di Korea Selatan, misalnya, melalui Pasal 5 UU Mahkamah Konstitusi ditentukan calon hakim haruslah berlatar belakang hakim, jaksa atau pengacara yang berumur minimal 40 tahun. Seseorang yang mempunyai pengalaman menangani masalah-masalah hukum di instansi-instansi pemerintah, badan usaha milik negara selama lebih dari 15 tahun juga dapat menjadi calon Hakim Konstitusi. Namun, calon Hakim Konstitusi juga dapat berasal dari kalangan perguruan tinggi yang terakreditasi sepanjang mempunyai pengalaman sebagai pengacara atau penasihat hukum dengan kedudukan setara atau lebih tinggi dari asisten profesor. Mereka yang pernah dipidana, didiskualifikasi sebagai pegawai negeri atau diberhentikan karena impeachment, tidak boleh mencalonkan atau dicalonkan sebagai Hakim Konstitusi.

Jerman mengatur persyaratan Hakim Konstitusi dalam UU Mahkamah Konstitusi yang juga merujuk pada UU Kekuasaan Kehakiman. Syarat umur minimal untuk pencalonan adalah 40 tahun. Mahkamah Konstitusi Jerman mempunyai dua panel yang masing-masing berjumlah 8 orang. 3 orang hakim dari masing-masing panel dipilih dari hakim-hakim Mahkamah Agung Federal (the Supreme Federal Court of Justice) yang mempunyai masa kerja sekurangkurangnya 3 tahun. Sedangkan untuk kualifikasi menjadi hakim menunjuk pada UU Kekuasaan Kehakiman yang menetapkan persyaratan yang sangat ketat. Meskipun semua profesi hukum di Jerman berangkat dari kualifikasi yang sama, namun persyaratan menjadi hakim biasanya lebih sulit. Hanya mereka yang mendapatkan nilai yang bagus pada ujian negara tahap 2 yang dapat menjadi hakim. Syarat lain, menyatakan kesediaannya menjadi Hakim Konstitusi dan selama menjadi Hakim Konstitusi tidak boleh merangkap profesi lain, kecuali menjadi profesor hukum di universitas-universitas Jerman. Persyaratan terakhir ini menunjukkan adanya penghormatan terhadap peran ilmuwan dalam pelaksanaan fungsi Mahkamah Konstitusi.

Berbeda dengan negara-negara di atas, di Amerika Serikat, syarat-syarat, baik syarat umur, kualifikasi personal maupun profesional Hakim Agung tidak ditentukan secara eksplisit dalam Konstitusi Amerika Serikat. Meskipun 
demikian, praktik menunjukkan syarat utama menjadi Hakim Agung adalah kualifikasi profesional. ${ }^{40}$ Terlepas dari tujuan-tujuan tertentu, para Presiden umumnya memilih calon-calon yang dipandang memiliki kompetensi tinggi dan integritas yang baik, meskipun tidak selalu orang terbaik dalam Asosiasi Pengacara. Berkenaan dengan pengalaman menjadi hakim, sejarah menunjukkan praktik yang berbeda. Sepanjang sejarah Mahkamah Agung Amerika Serikat, hanya setengah yang pernah menjadi hakim sebelum menduduki jabatan Hakim Agung. ${ }^{41}$ Presiden Eisenhower, misalnya, setelah mengangkat Chief Justice Earl Warren (sebelumnya menjadi Jaksa Agung California dan Gubernur California, namun tidak pernah menjadi hakim), membuat persyaratan pengalaman sebagai hakim untuk keempat calon Hakim Agung berikutnya yang diajukan olehnya. ${ }^{42}$ Dalam kenyataan, kebijakan para Presiden yang berasal dari Partai Republik umumnya menunjukkan menominasikan para calon Hakim Agung yang memiliki pengalaman menjadi hakim. Sebaliknya, para Presiden dari Partai Demokrat sebelum Presiden Clinton lebih menyukai mencalonkan mereka yang memiliki latar belakang politik atau administrasi pemerintahan. ${ }^{43}$

Pendekatan lain yang digunakan untuk menilai kualifikasi profesional para calon Hakim Agung di Amerika Serikat, yaitu melalui peran the American Bar Association (ABA). ${ }^{44}$ Sejak tahun 1947 organisasi tersebut memiliki Komite Kekuasaan Kehakiman Federal (Committee on Federal Judiciary) yang dalam berbagai kesempatan telah memainkan perannya untuk mempengaruhi proses nominasi dengan menggunakan beberapa klasifikasi untuk menunjukkan kualifikasi calon, meliputi: 'extremely well qualified' (sangat berkualifikasi), 'well qualified' (berkualifikasi baik), 'qualified' (berkualifikasi) atau 'not qualified' (tidak berkualifikasi). ${ }^{45}$ Awalnya, Komite tersebut mengusulkan agar diberi hak untuk mengusulkan calon, namun baik Partai Republik maupun Demokrat menolak usulan tersebut.

${ }^{40}$ Walter F. Murphy, et., al, Op. Cit., hlm. 146.

${ }^{41}$ Ibid.

42 Ibid., hlm. 147.

${ }^{43}$ Ibid.

${ }^{44}$ Ibid.

${ }^{45}$ Ibid. 
Sejarah Amerika Serikat menunjukkan perkembangan keikutsertaan ABA dalam proses seleksi. ${ }^{46}$ Presiden Truman menggunakan Komite tersebut untuk meminta masukan. Di masa pemerintahan Presiden Eisenhower, Komite tersebut bahkan menggunakan semacam hak veto terhadap calon-calon yang diajukan. Namun, praktik menunjukkan praktik berbeda pada masa setelah Eisenhower. Presiden Kennedy meneruskan nominasi delapan calon yang diajukan, meskipun Komite memberikan penilaian 'unqualified'. Presiden Johnson melakukan hal serupa. Sedangkan pada masa Presiden Carter, komisi seleksi yang dibentuk oleh Carter dalam hal tertentu telah mempengaruhi image Komite ABA. Tiga calon yang oleh Komite ABA dinyatakan 'unqualified' ternyata berhasil memperoleh konfirmasi Senat. Saat Ronald Reagan menjadi Presiden, kinerja Komite ABA mendapatkan perhatian dari masyarakat saat pendapat mereka terpecah dalam pencalonan Robert H. Bork dalam mana sepuluh anggota Komite menyatakan Bork sangat berkualifikasi, satu orang memilih 'not opposed', dan empat orang menyatakan tidak berkualifikasi. Pada tahun 2001, Presiden George W. Bush, bahkan menghentikan peran formal ABA dalam melakukan rating para calon sebelum finalisasi calon dilakukan oleh Presiden. ${ }^{47}$

\section{Mekanisme}

Pada saat berlangsungnya Constitutional Convention 1787, para pembentuk Konstitusi Amerika Serikat mengusulkan beberapa rancangan untuk memilih hakim federal. George Mason, Elbridge Gerry dan Oliver Ellsworth yang sangat menentang dominasi eksekutif, mempertahankan praktik yang telah dilaksanakan saat itu dan memberikan kewenangan kepada Congress untuk mengangkat. 48 Sebaliknya, Alexander Hamilton, James Madison dan Gouverneur Morris menginginkan kekuasaan eksekutif yang menunjuk hakim. Benjamin Franklin mengusulkan agar nominasi para hakim dilakukan oleh para pengacara atas dasar pertimbangan bahwa mereka akan memilih pengacara terbaik untuk menduduki posisi Hakim Agung. ${ }^{49}$ Adalah Hamilton yang pertama kali

\footnotetext{
${ }^{46}$ Ibid.

47 Walter F. Murphy, et., al, Op. Cit., hlm. 143.

48 Walter F. Murphy, Op. Cit., hlm. 142.

${ }^{49}$ Senator Charles McC Mathias, Jr, 'Advice and Consent: The Role of the United States Senate in the Judicial Selection Process', The University of Chicago Law Review 54, no. 1 (1987), 200-207, hlm. 200
} 
mengusulkan bahwa nominasi dilakukan oleh Presiden, sedangkan Senat memberikan konfirmasi. 50

Pandangan Hamilton ini dapat dibaca secara utuh dalam the Federalist Papers No. 76 dimana ia menjelaskan argumentasinya tentang perlunya pembagian kekuasaan antara Presiden dan Senat berkenaan dengan pengisian jabatan hakim. ${ }^{51}$ Pengusulan atau nominasi calon oleh Presiden disebutnya 'one man of discernment is better fitted to analyze and estimate the pecualiar qualities adapted to particular offices than a body of men of equal or perhaps even superior discernment'. Sedangkan keterlibatan Senat disebut Hamilton sebagai:

...the necessity of their concurrence would have a powerful, though, in general, a silent operation. It would be an excellent check upon a spirit of favoritism in the President, and would tend greatly to prevent the appointment of unfit characters from State prejudice, from family conncetion, from personal attachment, or from a view to popularity. And, in addition to this, it would be an efficacious source of stability in the administration. 52

Meskipun Hamilton mengakui adanya kemungkinan penolakan oleh Senat, namun ia lebih lanjut menyatakan, bahwa peran penting Senat dalam pengisian jabatan hakim dimaksudkan untuk memajukan 'a judicious choice of man' untuk jabatan hakim. ${ }^{53}$ Semula usulan Hamilton mengenai peran Senat dituangkan dalam frasa 'reject or approve', 54 namun akhirnya, yang disetujui adalah 'advice and consent'. Modifikasi atau perubahan ini justru memperlihatkan bahwa Senat memiliki peran dalam nominasi dan konfirmasi. ${ }^{55}$ Selain itu, 'dominasi' Senat dalam pengisian tersebut memperlihatkan karakter strong federalism yang dianut oleh Amerika Serikat karena Senat merupakan perwakilan Negara-negara Bagian.

Ketentuan Konstitusi Amerika Serikat sebagaimana tertuang dalam Art. II menempatkan Presiden dan Senat dalam situasi berhadapan dalam proses pengisian hakim federal, dan para pembentuk Konstitusi Amerika Serikat menyadari sepenuhnya akan munculnya konflik sebagai akibat dari design

\section{${ }^{50}$ Ibid.} hlm. 455.

51 Alexander Hamilton, James Madison, John Jay, The Federalist Papers, Mentor Books, New York, 1961,

${ }^{52}$ Ibid., hlm. 457.

53 Ibid., hlm. 455.

${ }^{54}$ Senator Charles McC Mathias, Jr, Op. Cit., hlm. 202.

${ }^{55}$ Ibid. 
tersebut. Sejarah telah menunjukkan dengan jelas tension yang terjadi, misalnya kegagalan President Nixon mendapatkan konfirmasi Senat bagi Clement Haynesworth dan Harrold Carswell, 'filibuster'56 saat Abe Fortas dinominasikan menjadi Ketua Mahkamah Agung untuk menggantikan Earl Warren pada masa Presiden Lyndon Johnson, serta nominasi Robert H. Bork dan Clarence Thomas pada masa Presiden Reagan. 57

Pada bagian terdahulu telah disebutkan bahwa Presiden dan Senat memiliki fungsi masing-masing berkenaan dengan pengisian hakim. Presiden berwenang mengusulkan, sedangkan Senat memberikan 'advice and consent'. Dalam hal ini, Senat memiliki dua fungsi yaitu to advise (memberikan pendapat atau rekomendasi) dan to consent (menyetujui). Dalam fungsi menyetujui secara inherent termasuk pula fungsi menolak (to reject). Dalam kerangka fungsi-fungsi tersebut, baik Presiden maupun Senat membangun dan mengembangkan mekanisme internal untuk memilih calon-calon Hakim Agung.

\section{Praktik Indonesia}

\section{Syarat-syarat}

UUD 1945 melalui Pasal 24A ayat (2) menentukan syarat-syarat Hakim Agung, yaitu harus memiliki integritas dan kepribadian yang tidak tercela, adil, profesional, dan berpengalaman di bidang hukum. Sedangkan syarat-syarat Hakim Konstitusi diatur dalam Pasal 24C ayat (5) yang menegaskan bahwa Hakim Konstitusi harus memiliki integritas dan kepribadian yang tidak tercela, negarawan yang menguasai konstitusi dan ketatanegaraan, serta tidak merangkap sebagai pejabat negara. Tidak diketahui secara pasti mengapa syaratsyarat tersebut, meskipun ada persamaan, namun terdapat pula perbedaan. Seorang Hakim Agung disyaratkan berpengalaman di bidang hukum, sedangkan Hakim Konstitusi harus menguasai konstitusi dan ketatanegaraan. Di negara

56 'Filibuster' adalah 'a dilatory tactic, esp prolonged and often irrelevant speechmaking, employed in an attempt to obstruct legislative action'. Bryan A. Garner (ed), Black's Law Dictionary, Seventh Edition, West Group, St. Paul, Minn, 1999, hlm. 643. Jadi, filibuster menunjuk pada suatu tindakan sebagai taktik yang dipraktikkan di Senat Amerika Serikat dengan tujuan mencegah terjadinya pemungutan suara, biasanya melalui perdebatan atau pidato panjang. Hal ini disebabkan hak untuk memperdebatkan sesuatu merupakan hak yang tidak dibatasi di Senat. Fortas akhirnya gagal mendapatkan konfirmasi Senat untuk menduduki jabatan Ketua Mahkamah Agung karena persoalan etika.

${ }^{57}$ Jason M. Roberts, 'Parties, Presidents, and Procedure: The Battle over Judicial Nominations in the US Senate' dalam Walter F. Murphy, et., al, Op. Cit., hlm. 179. 
manapun di dunia ini, seorang hakim, tidak semata-mata terbatas pada Hakim Konstitusi, haruslah menguasai konstitusi dan ketatanegaraan. Hal ini disebabkan konstitusi atau undang-undang dasar pada umumnya merupakan sumber hukum tertinggi yang ada dalam suatu negara. Kedudukan sebagai peraturan perundang-undangan tertinggi bermakna, pertama; semua pembuatan peraturan perundang-undangan harus bersumber dari asas, kaidah, cita dasar dan tujuan UUD. 58 Kedua; penerapan UUD didahulukan dari peraturan perundangundangan lain, dan ketiga; semua peraturan perundang-undangan lain tidak boleh bertentangan dengan UUD. ${ }^{59}$ Selain itu, seorang hakim dalam sumpah jabatan biasanya bersumpah atau berjanji memegang teguh UUD. Hal tersebut berarti UUD harus senantiasa menjadi sumber pertama pembentukan, penerapan dan penegakan hukum; serta adanya kewajiban mengembangkan UUD menjadi UUD yang hidup atau the living constitution agar tetap aktual sehingga mampu menjadi dasar pengelolaan negara dan masyarakat. ${ }^{60}$ Bagir Manan secara tegas berpendapat bahwa hakim harus senantiasa menggunakan UUD dan wajib mendalami UUD, bahkan Hukum Tata Negara pada umumnya. ${ }^{61}$ Oleh karena itu menurutnya 'tidaklah benar pendapat atau anggapan yang menyatakan hanyalah pengadilan yang menguji undang-undang sebagai satu-satunya badan yang menjaga UUD 1945 atau satu-satunya badan yang berwenang menafsirkan UUD $1945^{\prime} .62$

Norma-norma umum UUD 1945 tentang persyaratan Hakim Agung dielaborasi lebih lanjut dalam UU No. 14 Tahun 1985 tentang Mahkamah Agung sebagaimana telah diubah oleh UU No. 5 Tahun 2004 dan UU No. 3 Tahun 2009. Syarat-syarat Hakim Konstitusi diatur dalam UU No. 24 Tahun 2003 tentang Mahkamah Konstitusi yang diubah oleh UU No. 8 Tahun 2011 jo UU No. 4 Tahun 2014. UU No. 4 Tahun 2014 merupakan UU yang menetapkan Perpu No. 1 Tahun 2013 tentang Perubahan Kedua UU No. 23 Tahun 2004. Namun, pada tahun 2014,

${ }^{58}$ Bagir Manan dan Susi Dwi Harijanti, Memahami Konstitusi: Makna dan Aktualisasi, Rajagrafindo Persada, Jakarta, 2014, hlm. 161.

${ }^{59}$ Ibid.

${ }^{60}$ Ibid., hlm. 164.

${ }^{61}$ Ibid., hlm. 166.

${ }^{62}$ Ibid. 
UU No. 4 Tahun 2014 dibatalkan oleh Mahkamah Konstitusi melalui Putusan No. 1-2/PUU-XII/2014.

UU No. 14 Tahun 1985 membedakan syarat-syarat Hakim Agung yang berasal dari jalur karir dan non-karir, dimana calon berasal dari non-karir harus memiliki pengalaman di bidang hukum sekurang-kurangnya 15 tahun. ${ }^{63}$ Persyaratan calon Hakim Agung kemudian disempurnakan melalui UU No. 5 Tahun 2004. Syarat pengalaman, baik calon dari karir maupun non-karir ditingkatkan, ${ }^{64}$ dan melalui UU tersebut di Mahkamah Agung dimungkinkan kehadiran hakim ad hoc. ${ }^{65}$ Perubahan syarat-syarat kembali terjadi melalui UU No. 3 Tahun 2009 terutama berkaitan dengan syarat pengalaman yang mengalami pengurangan, dimana sebelumnya untuk jalur non-karir berpengalaman sekurang-kurangnya 25 tahun, menjadi 20 tahun. ${ }^{66}$ Sedangkan untuk calon yang berasal dari jalur karir, dipersyaratkan 20 tahun dengan sekurang-kurangnya 3 tahun menjadi hakim tinggi.67 Khusus untuk calon dari non-karir, syarat tingkat pendidikan adalah magister dan doktor, sedangkan calon dari jalur karir adalah magister, dan kedua jalur tersebut mensyaratkan dasar sarjana hukum atau sarjana lain yang mempunyai keahlian di bidang hukum. Tidak dapat diketahui dengan pasti mengapa syarat memiliki gelar magister diterapkan untuk calon yang berasal dari jalur karir. Dalam pandangan penulis, syarat yang lebih tepat adalah syarat-syarat yang mengarah pada syarat peningkatan profesionalisme hakim, misalnya syarat telah menjadi hakim tinggi sekurang-kurangnya 5 tahun atau pernah mengikuti pelatihan-pelatihan hakim, baik di dalam maupun di luar negeri. Syarat memiliki gelar magister berpotensi mendorong mereka yang ingin menjadi Hakim Agung menempuh jalur pendidikan lanjutan dengan berbagai cara, yang pada gilirannya akan mendorong terjadinya komersialisasi pendidikan tinggi hukum. Syarat lebih berat diterapkan untuk calon dari non-karir, yakni

${ }^{63}$ Pasal 7 ayat (2).

${ }^{64}$ Calon dari jalur karir: berpengalaman di bidang hukum sekurang-kurangnya 20 tahun (semula 5 tahun sebagai Ketua Pengadilan Tingkat Banding atau 10 tahun sebagai Hakim Tingkat Banding), sedangkan jalur nonkarir: berpengalaman dalam profesi hukum dan/atau akademisi hukum sekurang-kurangnya 25 tahun. Lihat Pasal 7 ayat (2).

\footnotetext{
${ }_{65}$ Pasal 7 ayat (3).

${ }^{66}$ Pasal 7.

${ }^{67}$ Ibid.
} 
memiliki ijazah magister dan doktor karena syarat ini bersifat kumulatif, bukan alternatif.

Berkenaan dengan syarat Hakim Konstitusi, selain syarat-syarat yang telah ditetapkan dalam UUD 1945, UU No. 24 Tahun 2003 mengatur bahwa seorang calon harus memiliki pengalaman di bidang hukum sekurang-kurangnya 10 tahun, sekurang-kurangnya berusia 40 tahun, dan tidak pernah dinyatakan pailit. ${ }^{68}$ Syarat-syarat mengalami perubahan melalui UU No. 8 Tahun 2011, baik untuk strata pendidikan, pengalaman, maupun umur. Seorang calon harus berijazah doktor dan magister dengan pengalaman di bidang hukum sekurangkurangnya 15 tahun dan/atau pernah menjadi pejabat negara. ${ }^{69}$ Untuk menjadi Hakim Konstitusi, seseorang sekurang-kurangnya berusia 47 tahun atau paling tinggi 65 tahun pada saat pengangkatan..$^{70}$ Perubahan persyaratan kembali terjadi berdasarkan Perpu No. 1 Tahun 2013, yang kemudian disahkan menjadi UU No. 4 Tahun 2014, meskipun pada akhirnya UU No. 4 Tahun 2014 dibatalkan oleh Mahkamah Konstitusi sebagaimana telah disebutkan di atas. Syarat strata pendidikan dari semula memiliki ijazah magister dan doktor, berubah menjadi hanya berijazah doktor. ${ }^{71}$ Syarat yang baru adalah syarat tidak menjadi anggota partai politik dalam jangka waktu paling singkat 7 tahun sebelum diajukan sebagai calon hakim konstitusi. ${ }^{72}$

Penambahan syarat Hakim Konstitusi melalui Perpu No. 1 Tahun 2013 yang kemudian disahkan menjadi UU No. 4 Tahun 2014 dipandang oleh sebagian orang bertentangan dengan UUD 1945,73 dan oleh karena itu mereka mengajukan permohonan pengujian UU tersebut ke Mahkamah Konstitusi. Terhadap syarat melepaskan keanggotaan partai politik, salah seorang Ahli dari Presiden yaitu Dr. Maruarar Siahaan, berpendapat tidak bertentangan dengan ketentuan UUD 1945,

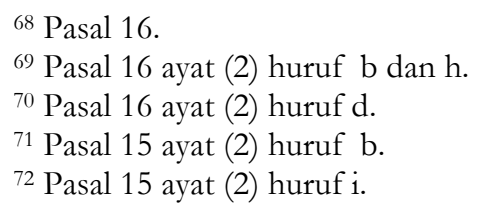

73 Pengujian UU No. 4 Tahun 2014 diajukan oleh 2 kelompok Pemohon, yaitu a.n. Dr. A. Muhammad Asrun dkk, serta Gautama Budi Arundhati, S.H., LLM, dkk. Lihat Putusan MK No.. 1-2/PUU-XII/2014, hlm 13. Pada pokoknya Pemohon I dan II mendalilkan bahwa pengaturan mengenai penambahan persyaratan untuk menjadi hakim konstitusi; mekanisme proses seleksi dan pengajuan hakim konstitusi; sistem pengawasan hakim konstitusi; komposisi dan kualifikasi anggota Panel Ahli; pembentukan Majelis Kehormatan Hakim Konstitusi; yang ditetapkan dalam Undang-Undang a quo serta kewenangan Komisi Yudisial untuk turut serta mengawasi hakim Mahkamah Konstitusi adalah bertentangan dengan UUD 1945 
khususnya pasal yang mengatur HAM dengan merujuk pada Putusan MK No. 81/PUU-IX/2011 mengenai uji materi UU No. 15 Tahun 2011 tentang Penyelenggaraan Pemilihan Umum terhadap UUD 1945. Dalam Putusan No. 81 tersebut, Mahkamah Konstitusi secara tegas menyatakan 'Pelepasan hak anggota partai politik untuk menjadi anggota komisi pemilihan umum bukan sesuatu hal yang bertentangan dengan konstitusi dan hak asasi manusia, karena justru hal tersebut diperlukan untuk menjamin fairness dalam pemilihan umum, yang artinya memenuhi/melindungi hak-hak peserta lain dalam pemilihan umum... ${ }^{\prime}{ }^{74}$ Bahkan, lebih lanjut Mahkamah Konstitusi menyatakan bahwa ketentuan pengunduran diri harus ditentukan jangka waktunya karena ketiadaan jangka waktu dapat digunakan sebagai 'celah oleh partai politik untuk masuknya kader partai politik ke dalam komisi pemilihan umum', dan oleh sebab itu menurut Mahkamah Konstitusi 'adalah patut dan layak jika ditentukan sekurangkurangnya 5 (lima) tahun sebelum yang bersangkutan mengajukan diri sebagai calon anggota komisi pemilihan umum'. ${ }^{75}$ Menggunakan pendapat Mahkamah Konstitusi tersebut, Dr. Maruarar menyatakan, 'penetapan batasan waktu paling singkat 7 (tujuh) tahun tersebut dinilai cukup untuk memberikan jaminan independensi dan imparsialitas seorang Hakim Konstitusi dalam memeriksa dan memutus perkara-perkara di Mahkamah Konstitusi, khususnya Perselisihan Hasil Pemilihan Umum (PHPU)' ${ }^{\prime}{ }^{76}$

Sebaliknya, Mahkamah Konstitusi menilai Pasal 15 ayat (2) huruf i tersebut dibentuk atas dasar 'stigma yang timbul dalam masyarakat' karena menurut Mahkamah 'sulit dilepaskan anggapan bahwa ayat ini tidak didasarkan atas kenyataan bahwa M. Akil Mochtar berasal dari politisi/Anggota DPR sebelum menjadi Hakim Konstitusi'.77 Selanjutnya dinyatakan bahwa 'stigmatisasi mencederai hak-hak konstitusional seorang warga negara yang terkena stigmatisasi tersebut padahal haknya dijamin oleh UUD 1945. Hak untuk menjadi Hakim Konstitusi bagi setiap orang adalah hak dasar untuk ikut dalam

\footnotetext{
${ }^{74}$ Putusan MK No. 1-2/PUU-XII/2014, hlm. 60.

${ }^{75}$ Ibid.

${ }^{76}$ Ibid.

${ }^{77}$ Ibid., hlm. 115-116.
} 
pemerintahan'. ${ }^{78}$ Mahkamah menegaskan bahwa 'original intent pengajuan Hakim Konstitusi dari DPR dimaksudkan bahwa DPR bebas memilih calon Hakim Konstitusi termasuk Anggota DPR yang memenuhi syarat, asalkan pada saat menjadi Hakim Konstitusi melepaskan keanggotaannya dari partai politik'.79 Dengan demikian, pengaturan yang didasarkan pada stigmatisasi yang dalam penerapannya penuh dengan permasalahan hukum, Mahkamah membenarkan dalil Pemohon mengenai syarat yang ditentukan dalam Pasal 15 ayat (2) huruf i tersebut beralasan menurut hukum. ${ }^{80}$ Akhirnya, karena pemohon mendalilkan tiga substansi hukum yang dibenarkan oleh Mahkamah dan yang menurut Mahkamah merupakan jantung atau substansi inti UU No. 4 Tahun 2014, ${ }^{81}$ maka Mahkamah menyatakan dalam putusannya bahwa UU No. 4 Tahun 2014 secara keseluruhan bertentangan dengan UUD 1945 dan menyatakan memberlakukan kembali ketentuan UU No. 24 Tahun 2003 sebagaimana telah diubah oleh UU No. 8 Tahun 2011.82

\section{Mekanisme}

Proses pengisian Hakim Agung dan Hakim Konstitusi memiliki beberapa perbedaan, antara lain lembaga atau badan negara yang terlibat dalam proses tersebut serta mekanisme internal yang dikembangkan oleh masing-masing badan. Berkenaan dengan Hakim Agung, berdasarkan ketentuan Pasal 24B UUD 1945, Komisi Yudisial (selanjutnya disebut KY) mempunyai kewenangan mengusulkan pengangkatan Hakim Agung ke DPR. Dalam melaksanakan kewenangannya tersebut KY melaksanakan pendaftaran dan seleksi calon, serta menetapkan calon Hakim Agung dan mengajukannya ke DPR.83 Berdasarkan Pasal 8 ayat (3) UU No. 3 Tahun 2009 tentang Perubahan Kedua Atas UU No. 14 Tahun 1985 tentang Mahkamah Agung, calon Hakim Agung yang diusulkan oleh KY dipilih oleh DPR 1 orang dari 3 nama calon untuk setiap lowongan. Ketentuan

\footnotetext{
${ }^{78}$ Ibid., hlm. 116.

${ }^{79}$ Ibid., hlm. 116-117.

${ }^{80}$ Ibid., hlm. 118.

${ }^{81}$ Ibid.

82 Ibid., hlm. 122.

83 Pasal 14 ayat (1) UU No. 22 Tahun 2004 tentang Komisi Yudisial.
} 
serupa juga dijumpai dalam Pasal 18 ayat (4) UU No. 18 Tahun 2011 tentang Perubahan Pertama UU No. 22 Tahun 2003 tentang Komisi Yudisial.

Ketentuan 3 calon untuk 1 lowongan Hakim Agung tersebut di atas dibatalkan oleh Mahkamah Konstitusi melalui Putusan No. 27/PUU-XI/2013 tentang Pengujian UU No. 3 Tahun 2009 dan UU No. 18 Tahun 2011 Terhadap UUD 1945.84 Pada dasarnya para pemohon mendalilkan bahwa ketentuan 3 calon untuk 1 lowongan telah memberikan kewenangan DPR melakukan pemilihan, dan bukan persetujuan sebagaimana diatur dalam Pasal 24A ayat (3) UUD 1945. Dalam pendapatnya, Saldi Isra selaku ahli menyatakan: kata persetujuan dalam ketentuan ini merupakan garis demarkasi bahwa DPR hanya sebatas menyetujui (setuju atau tidak setuju) dengan calon-calon yang dihasilkan dari proses di Komisi Yudisial. Kalau sekiranya DPR melakukan pemilihan, maka UUD 1945 akan menyebut dengan kata "dipilih" sebagaimana proses yang berlaku dalam pengisian anggota Badan Pemeriksa Keuangan. Dengan demikian, UUD 1945 tidak menghendaki DPR melakukan pemilihan, tetapi hanya sebatas persetujuan. 85

Pihak Pemerintah dalam sanggahannya menyatakan bahwa frasa 'persetujuan' harus dimaknai sebagai 'suatu proses, mekanisme, penilaian, untuk dapat disetujui atau tidak disetujui oleh DPR'.86 Pendapat yang sama juga disampaikan oleh pihak DPR. 87

Dalam putusannya, Mahkamah Konstitusi menyatakan: Pasal 8 ayat (2), ayat (3) dan ayat (4) UU MA, serta Pasal 18 ayat (4) UU KY, telah menyimpang atau tidak sesuai dengan norma Pasal 24A ayat (3) UUD 1945, karena ketentuan tersebut telah mengubah kewenangan DPR dari hanya "memberikan persetujuan" menjadi kewenangan untuk "memilih" calon hakim agung yang diajukan oleh KY. Demikian juga, ketentuan dalam kedua Undang-Undang a quo, yang mengharuskan KY untuk mengajukan tiga calon hakim agung untuk setiap lowongan hakim agung, juga bertentangan dengan makna yang terkandung dalam Pasal 24A ayat (3) UUD 1945. Frasa "3 (tiga) nama calon" dalam Pasal 8 ayat

\footnotetext{
${ }^{84}$ Pengujian diajukan oleh Dr. Made Dharma Weda sebagai Pemohon I, Dr. RM. Panggabean sebagai Pemohon II, dan Dr. ST. Laksanto Utomo sebagai Pemohon III. Putusan MK No. 27/PUU-XI/2013, hlm. 1.

${ }^{85}$ Putusan MK No. 27/PUU-XI/2013, hlm. 24.

${ }^{86}$ Ibid., hlm. 32.

87 Ibid., hlm. 37.
} 
(3) Undang-Undang Nomor 3 Tahun 2009 tentang Perubahan Kedua Atas Undang-Undang Nomor 14 Tahun 1985 tentang Mahkamah Agung (Lembaran Negara Republik Indonesia Tahun 2009 Nomor 3, Tambahan Lembaran Negara Republik Indonesia Nomor 4958) bertentangan dengan Undang-Undang Dasar Negara Republik Indonesia Tahun 1945 sepanjang tidak dimaknai "1 (satu) nama calon". 88

Berkenaan dengan pengisian Hakim Konstitusi, mekanisme internal yang dikembangkan oleh masing-masing lembaga pengusul memperlihatkan perbedaan. Pada saat Dr. Adnan Buyung Nasution menjadi salah satu anggota Dewan Pertimbangan Presiden, pengisian dari jalur Presiden menggunakan mekanisme seleksi dengan membentuk panitia seleksi. Beberapa ahli dengan latar belakang beragam bertindak sebagai pewawancara. Namun, praktik ini tidak dilaksanakan secara ajeg karena terdapat beberapa Hakim Konstitusi secara langsung ditunjuk oleh Presiden, antara lain, Hakim Konstitusi Prof. Maria Farida untuk masa jabatan kedua serta Hakim Konstitusi Dr. Patrialis Akbar.

Praktik di DPR juga beragam. Pada saat Prof. Mahfud MD dan Dr. Akil Mochtar diajukan oleh DPR, keduanya tidak menjalani mekanisme seleksi berupa wawancara dengan Panel Ahli. Namun, pada tahun 2014, DPR membentuk Panel Ahli yang beranggotakan 8 orang dengan latar belakang mantan Hakim Konstitusi, akademisi serta tokoh masyarakat. Kepada mereka, Komisi III memberikan keleluasaan melakukan penilaian untuk kemudian mengusulkan kepada DPR calon-calon yang memenuhi persyaratan. Selanjutnya, DPR melakukan pemilihan dengan cara pemungutan suara. Namun, pengalaman pada tahun 2014 menunjukkan bahwa calon-calon yang berhasil memperoleh nilai tertinggi dari Panel Ahli tidak serta merta dipilih oleh DPR untuk menjadi Hakim Konstitusi. Atau dengan kata lain, calon dengan peringkat tertinggi harus kalah oleh voting anggota-anggota DPR.

Sebaliknya, praktik yang relatif ajeg dilakukan oleh Mahkamah Agung. Mulai dari saat pertama kali pengisian dari jalur ini dilaksanakan, Mahkamah Agung tidak pernah menggunakan partisipasi masyarakat atau publik.

${ }^{88}$ Ibid., hlm. 51-53. 
Praktik-praktik di atas menunjukkan bahwa pengaturan dan pengisian Hakim Agung dan Hakim Konstitusi di Indonesia masih bersifat dinamis, dalam arti masih terjadi perubahan-perubahan pengaturan, terutama berkenaan dengan syarat-syarat dan mekanisme pengisian jabatan. Perubahan peraturan disebabkan munculnya tuntutan akan proses seleksi yang lebih terbuka dan akuntabel sehingga mampu menghasilkan hakim yang lebih profesional. Sayangnya, keinginan untuk menghasilkan hakim yang lebih berkualitas tidak selalu terwujud karena berbagai hambatan. Pengalaman pemilihan Hakim Konstitusi jalur DPR tahun 2014 memperlihatkan secara nyata bahwa kehadiran panitia seleksi tidak terlalu bermanfaat. Para anggota DPR seakan-akan tidak memperlihatkan kemauan untuk menggunakan hasil panitia seleksi, melainkan lebih mengedepankan preferensi pribadi atau politik. Selain itu, panitia seleksi juga tidak terlepas dari kritik, antara lain berkenaan dengan syarat anggota dan cara mereka melakukan tugasnya. Mekanisme fit and proper test tidak dilaksanakan secara wajar sehingga terdapat kesan, anggota panitia seleksi melontarkan pertanyaan-pertanyaan yang bersifat 'merendahkan' calon. Seharusnya, para anggota panitia seleksi lebih menempatkan dirinya sebagai orang yang ditugaskan untuk melakukan elaborasi kemampuan para calon dari berbagai perspektif.

Pada dasarnya, sejumlah persyaratan serta prosedur dan mekanisme pengisian Hakim Agung dan Hakim Konstitusi bertujuan untuk menghasilkan hakim yang baik. Aharon Barok menjelaskan sejumlah kriteria mengenai hakim yang baik (a good judge). ${ }^{89}$ Keseluruhan kriteria tersebut sesungguhnya dalam rangka pencapaian fungsi utama hakim, yaitu memeriksa dan memutus perkara. Untuk mencapainya, hakim harus menggunakan hukum yang tepat bagi perkara itu, baik melalui penerapan peraturan perundang-undangan maupun melalui pembentukan hukum baru. Dalam membentuk hukum baru, hakim harus memperhatikan dua tujuan sentral, yakni pertama, hakim harus dapat menjembatani 'gap' antara realitas sosial dan hukum, dalam arti hakim harus dapat mengadapatasi hukum untuk memenuhi kebutuhan perubahan kehidupan 307-309.

89 Aharon Barok, The Judge in A Democracy, Princeton University Press, Princeton, New Jersey, 2006, hlm. 
masyarakat. ${ }^{90}$ Kedua, hakim harus melindungi konstitusi dan nilai-nilai yang terkandung dalam konstitusi tersebut. ${ }^{91}$ Untuk mencapai dua tujuan utama tersebut seorang hakim haruslah bertindak obyektif, memperhatikan konsensuskonsensus sosial, memelihara kepercayaan masyarakat, dan menggunakan beragam sarana, meliputi penggunaan interpretasi, pengembangan hukum kebiasaan, penerapan 'teori weighing and balancing', serta penerapan metode perbandingan hukum. ${ }^{92}$ Secara tegas, Barok menyatakan adalah penting menggunakan sarana-sarana yang legitimate untuk mencapai hasil yang diinginkan. ${ }^{93}$

Secara teoretis, jabatan Hakim Agung dan Hakim Konstitusi bukanlah jabatan politik. Namun, pengisian jabatan Hakim Agung dan Hakim Konstitusi, meskipun sangat menekankan pada aspek kualifikasi profesional, dalam praktiknya pertimbangan-pertimbangan politik tidak dapat dielakkan. Dengan demikian, senantiasa terdapat dimensi politik dalam pengisian jabatan Hakim Agung dan Hakim Konstitusi. Praktik-praktik di Amerika Serikat, Korea Selatan, Jerman, bahkan Indonesia memperkuat argumentasi ini karena adanya keterlibatan Badan Perwakilan Rakyat atau Parlemen. Di satu sisi, keterlibatan tersebut bermakna positif sebagai wujud penguatan legitimasi calon yang terpilih. Namun, di sisi lain, keterlibatan dapat menimbulkan problem karena dapat terjadi politik tawar-menawar yang pada gilirannya pemilihan dapat menghasilkan hakim atas dasar preferensi politik atau bahkan personal.

Disadari, tidak mudah atau bahkan tidak mungkin menghasilkan suatu model pengisian jabatan hakim yang sempurna karena suatu model yang sempurna sekalipun tidak secara otomatis selalu menghasilkan hakim sesuai dengan yang diharapkan. Dalam konteks Hakim Konstitusi, khususnya, pengisian jabatan menjadi lebih kompleks karena by nature, Mahkamah Konstitusi merupakan suatu badan yang menyelesaikan sengketa yang dapat dikategorikan sebagai perkara-perkara politik.

${ }^{90}$ Ibid., hlm. 306.

${ }^{91}$ Ibid., hlm. 307.

${ }^{2}$ Ibid.

${ }^{93}$ Ibid. 
Akhirnya, kebutuhan akan adanya pembaharuan serta pentingnya sikap pengekangan diri menjadi tidak terelakkan lagi manakala pengisian jabatan Hakim Agung dan Hakim Konstitusi diletakkan dalam perspektif demokrasi guna menjaga reputasi kekuasaan kehakiman. Demokrasi bukan hanya berkenaan dengan suara mayoritas atau aspek formal demokrasi (seperti terjadi dalam pemilihan Hakim Konstitusi Indonesia melalui DPR tahun 2014). Lebih jauh dari sekedar proses tersebut, pemilihan harus didasarkan pada aspek demokrasi yang merujuk pada nilai-nilai dasar demokrasi (aspek substantif) yang merefleksikan nilai-nilai moralitas, keadilan, reasonableness dan itikad baik (good faith). ${ }^{94}$ Keseluruhan proses pengisian tersebut harus didasarkan pada pemahaman utuh: bukan sekedar memilih judge, melainkan justice.

\section{Penutup}

Berdasarkan analisis terhadap permasalahan di atas, dapat disimpulkan, pertama, pengisian jabatan Hakim Agung dan Hakim Konstitusi menunjukkan lebih bersifat politicking karena keikutsertaan Badan Perwakilan Rakyat atau Parlemen. Kedua, pembaharuan dan prinsip pengekangan diri perlu dilakukan oleh masing-masing cabang kekuasaan untuk meminimalkan bias politik.

\section{Daftar Pustaka}

Barok, Aharon, The Judge in A Democracy, Princeton University Press, Princeton, New Jersey, 2006.

Chase, Harold W, Federal Judges: The Appointing Process, University of Minnessota Press, Mineapollis, 1972, http:/ / en.bookfi.org

Clark, Mary L, 'Advice and Consent vs. Silence and Dissent? The Contrasting Roles of the Legislature in U.S. and U.K. Judicial Appointment', Louisiana Law Review 71, no.2, 2011.

David, René dan John E.C. Brierly, Major Legal Systems in the World Today, New York, The Free Press, 1978.

Epstein, Lee, et., al, 'Comparing Judicial Selection Systems', 10 Wm. E Marry Bill Rts. J, 7, 2001. 
Garner, Bryan A (ed), Black's Law Dictionary, Seventh Edition, West Group, St. Paul, Minn, 1999.

Gerhardt, Michael J, 'Federal Judicial Selection as War, Part Three: The Role of Ideology', Faculty Publications, Paper 976, 2002.

Ginsburg, Tom \& Nuno Garoupa, 'Building Reputation in Constitutional Courts: Political and Judicial Audiences', 28 Arizona Journal of International and Comparative Law 539, 2011.

Glendon, Mary Ann, et., al, Comparative Legal Traditions, Second Edition, West Publishing Co, St. Paul, Minn, 1994.

Hamilton, Alexander James Madison, John Jay, The Federalist Papers, Mentor Books, New York, 1961.

Jain, M.P, Indian Constitutional Law, 5th edition, Wadhwa Publisher Nagpur, 2006.

Mallesson, Kate dan Peter H. Russel (ed), Appointing Judges in an Age of Judicial Power: Critical Perspective From Around the World, University of Toronto Press, Toronto, 2006, <https:/ / books.google.co.id >

Manan, Bagir, Teori dan Politik Konstitusi, FH UII Press, Yogyakarta, 2003.

Manan, Bagir dan Susi Dwi Harijanti, Memahami Konstitusi: Makna dan Aktualisasi, Rajagrafindo Persada, Jakarta, 2014.

McC Mathias, Jr, Senator Charles, 'Advice and Consent: The Role of the United States Senate in the Judicial Selection Process', The University of Chicago Law Review 54, no 1, 1987.

Murphy, Walter F. et., al, Courts, Judges E Politics, An Introduction to the Judicial Process, Sixth Edition, McGraw Hill, Boston, 2005.

Ranawijaya, Usep, Hukum Tata Negara Indonesia: Dasar-dasarnya, Ghalia Indonesia, Jakarta, 1983.

Roberts, Jason M, 'Parties, Presidents, and Procedure: The Battle over Judicial Nominations in the US Senate' dalam Walter F. Murphy, et., al (eds), The Oxford Handbook of Law and Politics, Oxford University Press, Oxford, 2008.

Watson, Bradley C.S, Living Constitution, Dying Faith: Progressivism and the New Science of Jurisprudence, ISI Books, Wilmington, Delaware, 2009.

Whittington, Keith E, et., al (eds), The Oxford Handbook of Law and Politics, Oxford University Press, Oxford, 2008.

Yalof, David A, 'Filling the Bench' dalam Keith E. Whittington, et., al (eds), The Oxford Handbook of Law and Politics, Oxford University Press, Oxford, 2008

Yoo, John C, 'Choosing justices: A Political Appointments Process and the Wages of Judicial Supremacy', Michigan Law Review, Vol. 98, 2000.

UUD Negara Republik Indonesia Tahun 1945.

UU No. 14 Tahun 1985 tentang Mahkamah Agung 
UU No. 23 Tahun 2004 tentang Mahkamah Konstitusi

UU No. 3 Tahun 2009 tentang Perubahan Kedua Atas UU No. 14 Tahun 1985 tentang Mahkamah Agung.

UU No. 22 Tahun 2003 tentang Komisi Yudisial

UU No. 18 Tahun 2011 tentang Perubahan Pertama UU No. 22 Tahun 2003 tentang Komisi Yudisial.

Perpu No. 1 Tahun 2013 tentang Perubahan Kedua UU No. 23 Tahun 2004 tentang Mahkamah Konstitusi

UU No. 4 Tahun 2014 tentang Penetapan Peraturan Pemerintah Pengganti Undang-Undang No. 1 Tahun 2013 tentang Perubahan Kedua Atas Undang-Undang No. 24 Tahun 2003 tentang Mahkamah Konstitusi

Putusan MK No. 1-2/PUU-XII/2014 tentang Undang-Undang Nomor 4 Tahun 2014 tentang Penetapan Peraturan Pemerintah Pengganti UndangUndang Nomor 1 Tahun 2013 tentang Perubahan Kedua Atas UndangUndang Nomor 24 Tahun 2003 tentang Mahkamah Konstitusi Menjadi Undang-Undang terhadap Undang-Undang Dasar Negara Republik Indonesia Tahun 1945

Putusan MK No. 27/PUU-XI/2013 tentang Pengujian Undang-Undang Nomor 3 Tahun 2009 tentang Perubahan Kedua Atas Undang-Undang Nomor 14 Tahun 1985 tentang Mahkamah Agung dan Undang-Undang Nomor 18 Tahun 2011 tentang Perubahan Atas Undang-Undang Nomor 22 Tahun 2004 tentang Komisi Yudisial terhadap Undang-Undang Dasar Negara Republik Indonesia Tahun 1945. 